\title{
Encountering the Grotesque
}

\section{The Material Scribal Culture of Late Medieval Jewish Magic}

\section{Introduction}

Many spell procedures laid out in the medieval Jewish grimoire literature dictate the use of unusual or grotesque writing materials. ${ }^{1}$ Although writing with standard ink on parchment remains the norm, some grimoires prescribe nomina sacra or spells to be written on glass, fruit, eggshell, and parchments made from various skins (cat, snake, rabbit, and even human amniotic sac), and with liquids other than ink, such as human blood, blood of various animals, honey, and semen.

In this paper, I will present an abbreviated survey of unusual and grotesque writing material in late medieval Jewish magic texts. Although perhaps unsurprisingly, we have few (if any) extant physical remnants of these spells, my interest lies primarily in the prescriptive aspect of the magic. Why did Jewish practitioners of magic, as scribes, prescribe spells involving such unusual and, at times, repugnant material?

In magic that involves common materia magica (such as the usual parchment and ink), we are relegated to mining the nomina sacra, the methods for application, and the performance of the magic for connections between the prescribed magic and the promised effect. In magic that involves unusual and grotesque materia magica, however, we may be able to detect a specific prescriptional intent behind the media, and a specific connection between the media and the effect. However, we must exercise caution in this endeavor, as Bohak writes:

\footnotetext{
1 The term "unusual" is inherently fraught with imprecision, and is so context-bound as to be rendered useless unless we first determine the context in which it is to be used. For example, silver as a substrate might be fairly unusual when viewing the phenomenon of Jewish scribal culture as a whole. If we were to select a subset, however, such as scribalism within medieval Jewish magic, silver substrates are fairly commonplace. Further, a substrate or ink that may be considered unusual vis-à-vis the subset of the material scribal culture of medieval Jewish magic may be commonplace within a particular text. Thus, when affixing a label of "unusual" to a scribal material, we must remain conscious both of the milieu of the magic (that is, what would have been perceived as unusual to a practitioner of Jewish magic in the premodern era), and of our own milieu (that is, how the label of "unusual" is a heuristically useful term in our study of magic). If we are to use the term "grotesque" as a useful heuristic, then we ought to use it in a manner distinct from our use of "unusual". My inclusion of scribal media in this category in this paper is bounded to the psychological reaction it evinces from a reader; it is thus entirely subjective, and yet, useful. "I know it when I see it" seems to be the most sound parameter for distinguishing the grotesque from the unusual. Whereas unusual scribal material often may be a natural result of the magical genre without a spell-specific connection between material and intended effect, it seems that the grotesque is something more.
} 


\begin{abstract}
However, valuable as such an approach [of omnisignificance of the forms of magic] might be for the study of Jewish magic, it soon runs into three specific problems. First, the quest for the meaning of every little detail risks over-interpreting the data, and even the basic assumptionthat the individual components of a cultic activity have specific meanings-cannot be taken for granted. Second, and most important for the study of magical rituals, the Jewish magical practices (like those of many other societies) are very eclectic, and stem from several different cultural milieus [...]; thus, looking for their meaning within the Jewish cultural framework, when their origins may lie outside it, might lead to some very misleading results. Third, and most important for the present discussion, it must be stressed that the symbolic-cultural interpretation of magical rituals actually bypasses the issue of their rationality. The "thick" description of ritual seeks to show how the details of a given ritual might fit within the framework of the culture which produced it, but it does not help explain the gap between their cultural premises and nature's refusal to play by their rules. In other words, it shows us how a ritual might "work" in the cultural sense of the word, but not how it might actually work in achieving the results it proclaims. ${ }^{2}$
\end{abstract}

Here we are not concerned, as Bohak is, with the issue of how the prescribed magic might have actually functioned and brought about, psychologically or otherwise, an outcome that could have been interpreted by a practitioner as a satisfactory result. Thus, the third concern that Bohak raises, though an issue for the study of magic in general and even the study of the late medieval European Jewish variety, it is not an issue which we should address here, focusing as we are on the "back end," as it were, of spell creation. Bohak's second issue is one that we shall discuss whenever we find such connections, and one that we must remain conscious of at all stages of research. Bohak's first concern, of course, is one that is very difficult to safeguard against in objective terms.

\title{
2 Sources
}

Most of the texts upon which I drew for the research behind this paper are unpublished Hebrew and Aramaic manuscripts from the Vatican library. I have prepared a fully annotated and content-descriptive catalogue of the magic manuscripts in the Vatican library's collection; this forms the base of much of the data behind this paper.

\subsection{Vatican Manuscripts}

\subsubsection{Vat. ebr. 243}

This manuscript of 62 folios was written in Italy around the year $1500 .{ }^{3}$ It contains 186 itemized spells, although in actuality only 162 spells are contained therein; the numbering and contents do not always align, and in several places the numbering

2 Bohak 2008, 47.

3 See Beit Arié et al. 2008, 180-181. 
skips. ${ }^{4}$ The scribe either made a weak attempt at topical organization or copied from thematic grimoires wholesale, resulting in groups of spells that are topically bound peppered throughout the work. ${ }^{5}$

\subsubsection{Vat. ebr. 242}

Vatican 242 is an unusual manuscript. Written on paper in a late 15 th-century Italian semicursive hand, this short grimoire text is written in Hebrew. ${ }^{6}$ On f $31 \mathrm{r}$ the title reads, שלי זה ספר הרזים, "This Sefer haRazim [book of secrets] is mine," although it is not the ספר הרזים, a well-known Jewish grimoire of Late Antiquity. ${ }^{7}$ The incipit of the grimoire section reads: זה החלק יש בו ל' עניינים בכת של לילין, "This section contains 30 matters regarding the species of demons." It goes on to list a table of contents describing a veritable menagerie of medieval Jewish magic. Most of it is non-textual, lacking a verbal or written spell and relying instead on highly unusual materials and actions.

We might be tempted, bizarre as this text is, to assume that this manuscript is an autograph copy of the work, and that it is the conjuration of one imaginative scribe, executed for purposes other than practical use. Possible functions such a text could have served are entertainment or an illustration of the demonic powers in the world. It is unlikely that this manuscript is an autograph copy of the text, ${ }^{8}$ although we cannot rule out any hypothetical telos behind the text on this basis alone.

In terms of content, the case of Vatican 242 suggests a perception of association between grotesque scribal material and demonic forces (whether explicit in the spell or implicit in the fact of the magic's aggressive nature) in Medieval Jewish magic. We must further examine items of the text to see precisely how that expresses itself.

4 As follows: §1-56 intact, §§57-66 omitted, §67-144 intact, §§145-160 omitted, §161-186 intact. Two spells are set off as distinct sections, but are unnumbered (between $\S 115$ and $\S 116$, and after the last numbered spell, §186)

5 For example, $\S \S 2-7$ and $\S \S 127-129$ are wisdom spells, $\S \S 135-137$ are for childbirth.

6 See Beit Arié et al. 2008, 180.

7 See the classic edition and work on Sefer haRazim (Margalioth [ed.] 1966).

8 First, several items that are listed in the table of contents (viz. 17, 22, 24, 27, 28, and 30) are missing from the text itself. Several other items (numbers 13-16, 18-21, 23, 25, 26, and 29) are unnumbered. Second, there are discrepancies in terms of content between the table of contents and text itself. For example, the penultimate spell, which corresponds in subject matter to the penultimate spell listed in the table of contents (number 29, a spell to fly upon the wind), is followed by another spell, unnumbered, which should be the 30th and final item in the work. Item 30 in the manuscript's table of contents is listed as "to heal a fever." However, in the 30th item, we find another spell to fly upon the wind. Item 15, according to the table of contents, is an aggressive incantation to "inflame the mind of a person," whereas the text itself is a protective incantation to exorcise a demon. Interestingly, this incantation is ascribed to Rav Hanina, the rabbinic sage whose name is invoked in a number of Jewish Babylonian magic bowls containing anti-demonic spells. I find it unlikely that a scribe who was composing an original text would compose a table of contents in such slipshod a manner. 


\subsubsection{Vat. Ross. 356}

Written in Camerino, Italy in 1412 by an Ashkenazic scribe, "Jeroham b. Samson the Ashkenazi from Eger ${ }^{9}$ for Solomon b. Elijah,” this manuscript of 133 folios contains prayers and charms for travelers on folios $81 \mathrm{r}-94 \mathrm{v}$, and charms, spells, and amulets on folios 95r-100v. The grimoire that spans folios 95r-100v contains thirty-six spells (unnumbered) that span a wide range of magic genres.

\subsection{Shorshe haShemot}

Another major source that I utilized in my research is the mid-17th-century work, Shorshe haShemot (שרשי השמות, “Roots of the Names”), by Moshe Zacuto (ca.1625-1697). Zacuto was a prolific writer. Among his surviving works we encounter a fairly broad generic spread. He composed poetry, legal responsa, theoretical kabbalistic writings, commentaries on rabbinic texts, and magic texts. Zacuto's Shorshe haShemot is arranged (loosely) alphabetically; each entry is arranged according to the first letter of the first word in a series of voces magicae. These words can be classified as angelic, divine, nonsensical, and foreign-language ${ }^{10}$ in nature. After each entry of a magical word or series of words, Zacuto provides the derivation of the name, if he had either a tradition as to the name's derivation or the creativity to discover it himself. He then goes on to describe the manner in which the names work, the kabbalistic significance of the names, or the method by which they are to be used. Often the entry will end with either an ascription to an earlier source, with a note that Zacuto tested the spell, confirming its efficacy, ${ }^{11}$ or both.

As one would expect from a text that purports to be an encyclopedic compendium of spells from earlier grimoire literature, there are many parallels between the contents of Zacuto's work and the magic that we find in extant manuscripts that predate this 17th-century compilation. A large number of the items are explicitly sourced, but there also remains a considerable percentage of anonymous items. It is fairly easy to detect the hand of Zacuto in the composition of the work, and he seems to have been honest with attribution. Due to the lack of a critical text (such a work would be a monumental undertaking), I utilized the printed edition in my research presented here, in conjunction with several of the earliest manuscripts of the work. ${ }^{12}$

9 The Czech city Cheb (German: Eger), on the river Ohře.

10 Arabic (e.g. s.v. אבליס), Greek, Latin, and other languages are used.

11 See, e.g.s.v. שמשיס.

12 Including MS NLI MSS-D 266 and University of Manchester Library, Gaster Hebrew MS 765. 


\section{Continuity and Innovation in Medieval Jewish Magical Tradition}

Before we investigate the question of Jewish magicians' intentions when composing or prescribing magic processes that employ grotesque elements, we must first address the question of the provenance of the texts from which we draw our data. It would be methodologically less-than-optimal to analyze magical texts from wildly different time periods in the same stroke, or to do so without first establishing the possibility that a thread of continuity runs through them. While it is certainly the case that the scribe-authors of late medieval Jewish grimoires exercised a certain degree of creativity, many of their spells find their sources in earlier texts, some of which are attested in the magical literature preserved in the Cairo Genizah.

In a recently-published article, Bill Rebiger discusses writing materials used in ancient and early medieval Jewish magic. The titular spell, one intended to cause a person who has become wayward and a sinner to repent, is to be written on three ribs of a sheep or other domesticated animal. The ribs are subsequently cast into a fire. ${ }^{13}$ Minor issues with his specific argument surrounding this particular spell aside, his analysis is intriguing. He does not note (nor is it pertinent to his argument) that this very same spell appears several centuries later in an early 15th c. northern-Italian manuscript written in a Sephardic semi-cursive hand. My own transcription and translation follows:

\begin{abstract}
Vat. ebr. 188f. 84v
קח ג' צלעות של שור או של כבש וכתוב

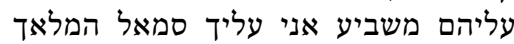

ולמפריאל המלאך. הפכיאל עליאל המלאך ופואל המלאל ומלאל

המלאך זהריאל המלאד המלאד צדקיאל המלאך המלאך ופריאל

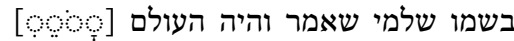

שתהפכו לבו וכליותיו של פלו' בל פליה פלו'

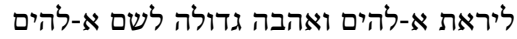

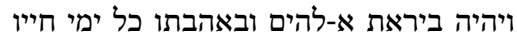

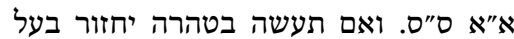

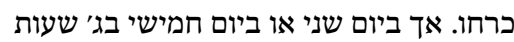

ביום ותבעיר התנור יפה ותשליום שניר הצלעיר בגות

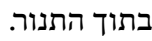

\section{T-S K1.28f. $2 \mathrm{v} 14$}

להפוך דעת האדם כת[וב] על ג' צלעות של כבש או

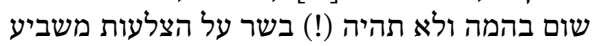

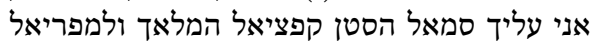

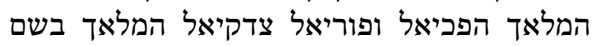

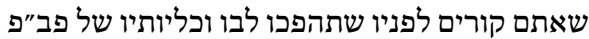

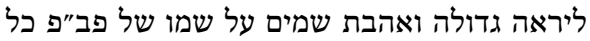

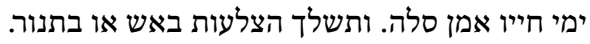

13 Cf. Rebiger 2017, 351-352

14 Schäfer/Shaked (eds.) 1994, 137-138: CUL TS K1.28, fol.2b/13-21 


\section{Vat. ebr. 188f. 84v}

Take three ribs of an ox or of a sheep and write on them,

"I adjure you Samael the angel, and Mafriel the angel, Hafkhiel the angel and Puriel the angel, Zahariel the angel and Tzadkiel the angel,

in the name of the One who spoke and the world existed [...], ${ }^{15}$

that you turn the heart and kidneys of soand-so son of so-and-so to the fear of God and great love toward God. And may he be in [a state of] fear and love of God all the days of his life. Amen! Amen! Selah! Selah!”

And if you do so in [a state of] purity he will repent against his will. Just on a Monday or a Thursday at three hours into the day, stoke the furnace well and cast the ribs into the furnace.

\section{T-S K1.28f. 2v}

To turn the mind of a person:

Write on three ribs of a sheep or of any domesticated animal (and there should be no flesh on the ribs),

"I adjure you Samael the Satan, Kaftziel the angel and to Mafriel the angel and Hafkhiel and Puriel and Tzadkiel the angel, in the name of the One before whom you bow, that you turn the heart and kidneys of so-and-so son of so-and-so to great fear and love of heaven on the name of so-and-so son of so-and-so, all the days of his life. Amen! Selah!"

And cast the ribs into a fire or furnace.

Minor differences notwithstanding, ${ }^{16}$ this spell clearly serves as a striking example of continuity of traditions between the earlier medieval Jewish magic preserved in the Cairo Genizah and later medieval European Jewish magic. ${ }^{17}$

The examples of spells found in the medieval Jewish grimoire tradition that reflect more-or-less unchanged versions of spells found in texts from the Cairo Genizah problematize the assignment of a medieval European milieu to these grimoires' content, or at least doing so in a wholesale manner. Proper analysis of these spells in an all-encompassing, thorough, item-by-item fashion is a desideratum.

15 These vocalized circles are strikingly similar to the tetrapuncta that Second Temple-era Jewish scribes employed to signify the tetragrammaton. See Tov 2004, 206-207.

16 Viz., the designation of Samael as "the angel" as opposed to "Satan," the difference of two of the angelic names, the excision of the divine invocation, and the addition of more detailed instructions. It is intriguing to note that Zacuto records the angelic name הפכיאל (ad loc.) and writes simply "These angelic names have great power in adjuration in the name of Samael Afiel Tamtiel," though no result or effect is listed. This could be a preservation of the adjuration of Hafkhiel along with Samael, though the spell itself has fallen away.

17 As another example we may cite Shorshe haShemot (ב:סז), where we find a love spell involving the use of a strip of cloth from a victim's clothing as a wick for a candle upon which are inscribed the nomina sacra. This spell is similar to Genizah love spells (TS AS 142.174, fols $1 \mathrm{r}$ and $1 \mathrm{v}$, cloth amulet, discussed by Rebiger 2017) that involve a clothing item of the victim. Although the voces magicae may differ, and the late medieval spell operates through the sympathetic magic act of burning the candle, thus inflaming the heart of the cloth wick's owner, they both involve clothing of the victim, and may stem from the same tradition. 


\section{The Magic}

\subsection{Human Blood}

Human blood plays a relatively minor role in the scribal aspect of late medieval Jewish magic. I have located a number of spells ${ }^{18}$ from three different sources prescribing different spell-texts but all involving the writing of magic letters on the forehead of the patient (see below, 4.5.1 for discussion of these spells), with the blood of the patient's own nosebleed serving as ink.

As in magic found in the Cairo Genizah and other early medieval Jewish magic, blood often is associated with love magic. ${ }^{19}$ In the magic texts surveyed in this paper, we find only one human blood-magic act prescribed as a love spell. In Vat. 243 §36, blood is to be drawn from fourth finger, and is to be used as ink to write on vellum:

Love: Two or three days after the molad [mean lunar conjunction], go to an open place, pierce your fourth finger and extract blood from it. Write these names on vellum [...] and shout these names in a loud voice. Go to a place where she goes or passes, bury it there, and you will see a wonderful result.

Although a connection between the calf vellum and the new moon ${ }^{20}$ cannot be ruled out, the connection between the specification of the fourth finger and the effect of the love magic is unmistakable. The concept of the vena amoris is found in late medieval Jewish sources, as in Abraham Zacuto's work on history, Sefer Yuhasin (ca. 1505):

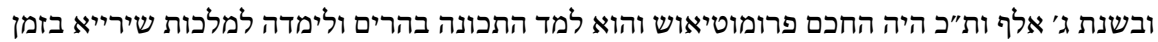

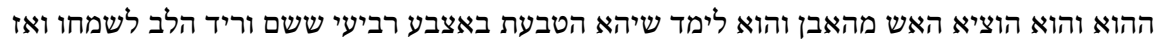

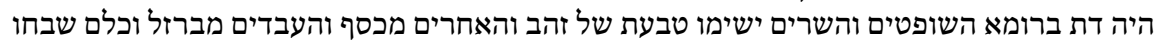

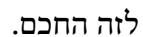

And in the year 3420 [ca.1780 BCE] lived the wise man Prometheus, who learned astronomy in the mountains. He taught it to the Syrian kingdom at that time. He brought fire forth from stone. He taught that the ring should be worn on the fourth finger, for there is the vein of the heart to make it glad. Thus came about the custom in Rome that the senators and the rulers would wear a gold ring, and the rest of the people would wear a ring of silver, and the slaves a ring of iron. Everyone praised this wise man. ${ }^{21}$

18 Shorshe haShemot א:רפו (s.v. בקם (s.v. בקילא אופילה) and MS Vatican Rossini 356f. 100r-100v; MS Vat. ebr. 243, §85.

19 See, e. g., Swartz 2006, 312.

20 For other bovine-lunar associations, consider Nanna/Sin, the Mesopotamian moon god, and his depiction as a bull. This depiction has wide-ranging significance in Sumerian and Akkadian texts. A ca. 8th-c. Bethsaida stele provides a depiction that is perhaps relevant. Although the horns are compared to those of the gazelle, the new moon's "head" is described as that of a calf in the humorous story related in b. Roš Haš. 22b.

21 Zacuto 1962, 234 a. 


\subsection{Animal Blood}

Animal blood found a certain degree of popularity in ancient magic, ${ }^{22}$ although its use seems to have continued into the medieval era in a more measured degree. Magic texts from the Cairo Genizah prescribe the writing of spells in various animals' bloods, some of which are discussed by Rebiger and others. In the later medieval Jewish magic recorded in the grimoire literature, animal blood is used much more sparingly.

Although halakha has nothing particularly negative to say regarding the blood of pure (kosher) animals, ${ }^{23}$ there is still a taboo, to employ the Frazerian term, surrounding it. Biblical and rabbinic law forbid the consumption of animal blood, ${ }^{24}$ and the blood of fowl and undomesticated mammals must be buried ritually after their slaughter, according to biblical and rabbinic law. ${ }^{25}$ In the contemporary (with these magic texts) standard halakhic work, the Shulhan Arukh, Yosef Karo codifies the statement of an earlier halakhist, מי ששחט הוא יכסה ואם לא כיסה וראהו אחר חייב לכסות ("The one who slaughters should be the one who covers [the blood], but if they did not cover [it] and another person saw them, [the other person] is obligated to cover [the blood].”) ${ }^{26}$

It is somewhat surprising, then, to find spells involving the use of fowl blood as ink, as in the following spell.

\section{Vat. ebr. $243 \$ 25$}

שלא יזק ולא יאבד דם מעולם כתוב בדם תרנגולת שחורה בקלף צבי כשר אלו השמות בטהרה [...]

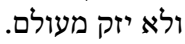

In order never to be harmed or lose blood, write in the blood of a black hen on deer parchment that is valid to use for holy scrolls when he is in a pure bodily state these names [...] and he will never be harmed.

The connection between the blood as ink and the prevention of bodily harm or blood loss is clear, although the reason for the specification of fowl-blood, and that of a black hen in particular, is unclear. The seal sequence ("names") is found in other medieval Jewish magic texts, although with slight variation in described function. ${ }^{27}$ It is likely that the use of fowl-blood only finds accepted use due to its precedence in earlier magic, especially the time-hallowed Sefer haRazim. ${ }^{28}$

22 For Sethian magic with donkey's blood, see Amirav 2005, 136. See also Bohak 2008, 203.

23 Although the blood of non-kosher animals, and particularly pig's blood, is found in several instances, seemingly all with the intention of shocking the reader.

24 Gen 9:4; Lev 3:17, 7:26-27, 17:10-12; Deut 12:22-25; b. Ker. 22a; Yoreh De’ah §66.

25 Tur Yoreh De'ah §28.

26 Shulhan Arukh Yoreh De'ah, §28:8.

27 In Vat. ebr. $243 \S 178$, it is for favor and protection, and in Vat. ebr. 239/2f. 10r, it is "to dwell securely in wilderness and city."

28 See Gruenwald 2011, 172ff. 


\subsection{Semen}

Vat. ebr. $243 \S 68$

לאהבה כתוב זה על תפוח אקנאה קאשטור פרגחן ואח"כ תדבק מזרעך על התפוח ואחר שיבש תן לה לאכול כהתוב

Love spell: Write this on an apple-[...], and then spread your semen on the apple. When it is dry, give it to her to eat.

In this spell, semen as a scribal medium is not employed as the ink, strictly speaking, but rather as a filler for the engraved magic words, or alternatively as a liquid covering or veneer to coat the writing, as in Vat. ebr. $242 \S 3$ (see above, 4.2). Presumably the spell is supposed to function by the voces magicae imbuing the apple, symbolizing love, ${ }^{29}$ with magical power, and then the semen specifying that that power be sexually connected to the practitioner, from whom the semen derives. Upon ingesting the apple, the magic takes effect on the woman. Also potentially at work here is a sort of mirroring act of the sin of Adam and Eve, in which Eve gave of the forbidden fruit to תן לה לאכול Adam to eat (Gen 3:6) alluded to in the phrasing of the spell instructions "give to her to eat," as opposed to the simpler formulation expected "and after it is dry, she should eat it" (ואחר שיבש תאכל).

The use of semen is particularly shocking considering both its impure status and the prohibition against its procurement in Jewish law. ${ }^{31}$ To quote again from a contemporary work of the manuscript in which this particular spell is recorded:

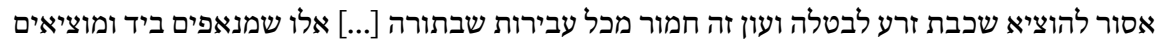

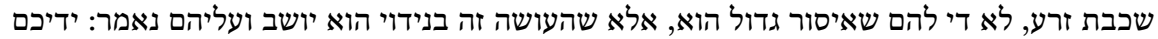

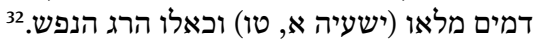

It is forbidden to ejaculate semen in vain. This $\sin$ is more severe than any other $\sin$ in the Torah [...] Those who fornicate with the hand and ejaculate semen, not only is it a great sin, but he who does this is excommunicated, and regarding him it is said "your hands are full of blood" (Isaiah 1:15) and it is as if he has killed a person.

How this spell came to be in such a milieu can be explained only by the precedence of seminal magic in earlier Jewish magic. ${ }^{33}$

29 The use of apples in love magic is well-attested. See Saar 2017, 38.

30 Although it is certainly possible that this is simply an incidental linguistic parallel, as similar formulations occur in other cultural contexts.

31 See Satlow 1994.

32 Shulhan Arukh, 'Even ha'Ezer §23:1-2.

33 Swartz 2006, MS TS AS 143. 229,3. 


\title{
4.4 Amniotic Sac
}

A minor grimoire called "The Seven Levels" which originates in the Book of Raziel the Angel is found embedded in several other medieval Hebrew grimoires. ${ }^{34}$ Vat. ebr. 243 records the use of prepared amniotic sac in several of its amulets. The mismatch between the type of magic and the materia (amniotic sac) suggests that the author-scribe of this composition simply favored the use of amniotic sac as a substrate. Why this is so is unclear.

Amniotic sac does find its way into medieval Jewish magic outside of the confines of Raziel, where it falls squarely into the function which we would expect of it.

\begin{abstract}
Shorshe haShemot p.207 \$9

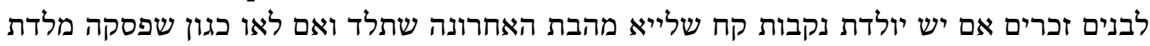

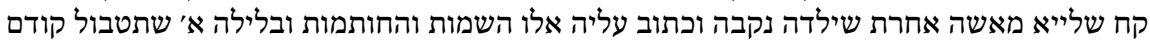

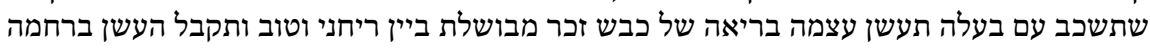

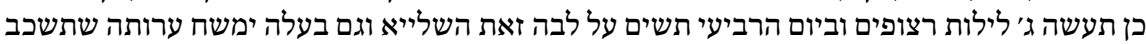

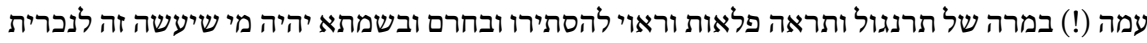

For male children: If there is a [woman] who is giving birth only to female children, take the amniotic sac from the last girl that she gave birth to, and if [this is not possible], for example, [in a case in which] she has passed menopause (?), take the amniotic sac of another woman who had a female child and write upon it these names and seals. And on the first night after she ritually immerses, before she lies with her husband, she should cover herself in the smoke of male sheep's lung that has been cooked in good and pungent wine, and she should receive the smoke in her womb. Thus should she do for three consecutive nights. And on the fourth day, she should place over her heart this amniotic sac, and her husband should anoint [his/her] genitals with chicken bile, and they will see wonderful results. And it is fitting to conceal [this spell]. And anyone who does this to/for a gentile woman shall be excommunicated.

\subsection{Human Body}

Unsurprisingly, spells written on the body all seem to be intended to affect the body itself-whether by ameliorating bodily issues such as difficult childbirth, narcolepsy, or nosebleeds, or by imbuing the body with protective magical power (such as making the skin impervious or making the practitioner immune to drowning).

\subsubsection{Forehead}

Although in the modern era nosebleed is not usually thought of as anything more than a nuisance, it seems that medieval Jews thought otherwise; spells to stop nosebleeds

34 E. g., MS Vat. ebr. 243, §§94-100. 
abound. In the medical section in the Babylonian Talmud tractate Gittin, nosebleed is also addressed, and six spells and therapies are cited..$^{35}$ Most of the medieval Jewish healing spells for nosebleeds that I have encountered involve the writing of magic names on the forehead of the patient. This seems to have no precedent in the talmudic magico-medical lore on nosebleeds. So we ask with regards to the late-medieval prescription: Why the forehead?

Vat. Rossini 356f. 100r-v

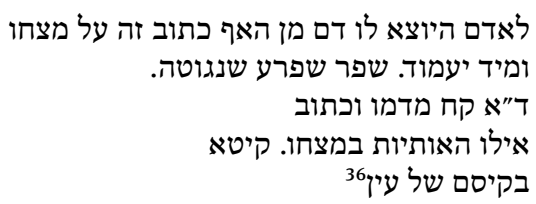

For a person who has a nosebleed, write this on his forehead [in ink] and it will stop immediately. ŠPR ŠPR ${ }^{\complement}$ ŠNGWTH

Another: Take from his blood and write these letters on his forehead. QYTA BQYSM ŠL ${ }^{\Upsilon} \mathrm{YN}^{37}$

Vat. ebr. $243 \S 85$

לדם היוצא מן הנחירים כתוב על מצחו זה השם אל"י פילפילי"ו ויעמד מיד

For blood that is running from the nostrils, write on his forehead this Name: ALY PYLPYLYN ${ }^{38}$ and it will cease immediately.

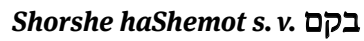

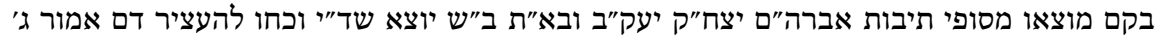

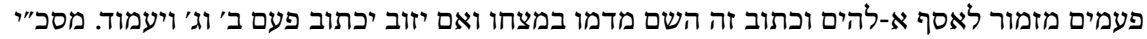

BQM Its source is from the final letters of Abraham, Isaac, and Jacob. Its power is to stop blood. Say psalm 79 thrice, and write this Name on the patient's forehead with their blood, and if it continues to flow, write it a second, a third time, and it will cease. From a manuscript.

The forehead and nose are seen as paired body parts in several instances in rabbinic literature. The most frequently-cited context of their pairing is when the forehead and nose together comprise the essence of the human face for purposes of recognition.

35 b. Git 69a. See Geller 2000.

36 These nomina barbara may be related to or derive from the expression "טול קיסם מבין שיניך/עיניך" ("remove the splinter from between your teeth/eyes." Although the reading עירין with obviously a corruption under the influence of טול קורה מבין עיניך that follows it, the corrupt version of the text had much currency among medieval rabbinic writers and was obviously the version of the aggadah that was familiar to the progenitor of this spell. See b. B. Bat. 15b, b. 'Arak. 16b, Ruth Zuta 1:1, and for medieval writers who perpetuate the corrupt text and potentially served as a source for our magic practitioner, see Menahem Meiri on mAvot 1:16 [17] (s.v. ואמר אח"כ).

37 Alternatively, the unintelligible "Summer in (?) the splinter of the eye."

38 The possibility that these nomina barbara derive from a medical text prescribing peppers (Aramaic and Hebrew פלפלין, Arabic فلفل) should not be discounted. 
b. Yebam.120a

תנו רבנן: פדחת ולא פרצוף פנים, פרצוף פנים ולא פדחת אין מעידין עד שיהו שניהם עם החוטם.

The rabbis taught: [If the witnesses saw] the forehead and not the face, or the face and not the forehead, they cannot testify [that it was the husband whom they saw die] until they see both the forehead and the face together with the nose.

Here, the Talmud discusses the requirements for the testimony of witnesses to a husband's death to free a woman to remarry. Although in none of the classical rabbinic phrasings are the forehead and nose alone singled out as identifying features, already in the geonic period, formulations of this ruling began to circulate with the "face" element excluded, as in the following quote from Simeon Qayyara's Halakhot Gedolot (ca. $850 \mathrm{CE}$ ).

נפל במים שאין להם סוף בשני עדים ודאי מימת מיית לגבי ממון נחתין יורשים לנכסיו לגבי אשה אחמירו ביה רבנן עד דאמרי סימני פדחת עתוף וחופי מטמו ושאר סימנין שלו.

If a man fell into waters that have no end in the presence of two witnesses, he has certainly died. For monetary matters, the inheritors may descend upon his possessions. For marital matters, the rabbis were stringent until the witnesses can testify as to the characteristics of his forehead and nose, and his other physical characteristics. ${ }^{39}$

The forehead and nose are paired in non-legal contexts, as well. In the following midrashic phrase-by-phrase explication of Qohelet 12:2, ${ }^{40}$ the "sun and light" are interpreted as a reference to the forehead and the nose.

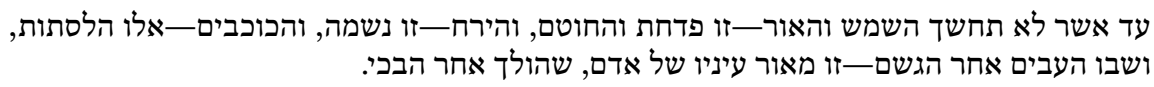

"Before the sun dims, and the light" (Qoh 12:2) - this refers to the forehead and the nose, "and the moon"-this refers to the soul, "and the stars"-this refers to the cheeks, "and the clouds return after the rain"-this refers to the light of the eyes of a person, which departs after crying. ${ }^{41}$

Having established the association between the forehead and the nose in medieval Jewish literature, the motive behind the selection of the forehead as a scribal substrate in the context of a spell intended to affect the nose is clear. The voces magicae are inscribed on the limb most closely associated with the affected organ, and the magic flows between them. Simple practical difficulty of writing on such a flexible and contoured surface as the human nose is most likely the reason that the nose itself is eschewed as a substrate. The forehead thus serves as a suitable substrate that was

39 Halakhot Gedolot $\S 31$.

40 Also found in Lev. Rabbah 18:1 and Qoh. Zuta, ad loc.

41 b. Šabb. 151b. 
seen as physiologically connected to the nose. The use of the nosebleed blood as ink in conjunction with the forehead substrate would have been thought of as a powerful formulation of an anti-nosebleed spell.

In addition to nosebleed spells, I have found several exorcism spells prescribed to be written on the forehead..$^{42}$ Again, the reason for the selection of the forehead is clear-the nose is the focus in the spell, and the spirit is to be extracted from the nostrils. The same motive can be detected in the prescription of exorcistic spells to be written on the hand (see below, 4.5.2).

\subsubsection{Hand}

Of the very popular genre of dream request spells, ${ }^{43}$ several are prescribed to be written on the hand..$^{44}$ It is possible that this is due to the (potential) position of the hands beneath the head, where nearly all dream request amulets are prescribed to be placed.

In one exorcism, Zacuto prescribes a series of nomina barbara to be written on the hand of the afflicted, and four other nomina to be written, each on one finger. Presumably, the writing of the sacred names on the fingers is to protect them from a potentially catastrophic exit by a spirit. Bound and protected as they are by the names, the spirit cannot but exit from the single finger that is left unbound, and from which the exit of spirits was deemed safe in medieval Jewish exorcistic practice. ${ }^{45}$

Many spells that involve the use of the hand or parts of the hand as a scribal substrate are not designed to function with the imbuing of magical power in the substrate. Several exorcisms that involve writing on the hand of the patient prescribe the licking of the ink off of the hand as the exorcistic mechanism. ${ }^{46}$ Imbibing magical writing by licking the written spell off of the body is found in several contexts, going back to earlier medieval Jewish magic. In this scribal act, the magic effect or energy is not transferred to the substrate (or shared in the ink-substrate nexus), as it is in the creation of amulets, but rather is preserved in the physical ink that forms the letters comprising the voces magicae. We may then ask: what is the conceptual function of the substrate? If the ink alone is acting as the substance that is magically formed (in the very act of writing), of what use is the specification of a substrate, and in our case, such a

42 Shorshe haShemot s. v. רדפיאל.

43 Idel 2006, esp.91-119.

44 Shorshe haShemot s.v. אדונירם and רפריאל.

45 Although it is not stated, it is fair to assume that the finger that is left unbound is the little finger. The little finger is frequently used in rabbinic literature as the superlative extremity of the body (see, e. g. Gen. Rabbah 46:4, b. Ketub. 103a, and Avot deRabbi Natan 2:1). While the late-medieval and early modern references to exorcism by way of the little finger generally refer to the pinky toe of the left foot and not the little finger of the hand, it is possible that an earlier form of this belief is operating here.

46 Shorshe haShemot s. v. באבוגיff. 
specific and bizarre one, at that? Rebiger cites a Genizah wisdom spell to be written on the fingernail and licked off; this spell (or a later reflex of it) is found in Zacuto's work. ${ }^{47}$ Rebiger further points to the similarity to the popular Ashkenazic schoolchild initiation magic rite. ${ }^{48}$ We may distinguish between these two magical acts in that in the case of the school initiation rite, the writing on a cake imbues the cake with magical efficacy, whereas here, it is the material writing in and of itself that provides the magical effect.

These substrates seem to go together, as it were; smooth, hard, non-porous materials are favored for dissolving-writing magic. Thus, we can state that it is likely that the selection of the fingernail is due more to its physical characteristics than to its magical implications, although that may vary in a case-by-case basis. For example, we might connect the healing of a venomous bite ${ }^{49}$ with writing on the hand and the subsequent licking off of the voces magicae with the ancient idea that wolves, lions, and other animals have venom in their claws which they inject into their prey. ${ }^{50}$ The mechanism would then be a sort of sympathetic magic by which the locus of writing focuses the healing power of the magic writing, which is then ingested (licked) by the patient. Thus the patient simultaneously is performing a ritualistic licking action which takes effect by magical imitation, and absorbing the magic into the body where it can begin to heal. ${ }^{51}$

\subsubsection{Mouth}

Writing in the vicinity of the mouth, as previously shown with regards to the hand, is prescribed for exorcism. The mouth was thought of as one of the entryways by which an evil spirit might come to possess a person. Thus, it is entirely logical that medieval Jewish sorcerer-scribes should compose spells to be written on the mouth. What is surprising is that writing on the mouth is so rarely prescribed. ${ }^{52}$ What precisely is intended by "mouth" in those few prescriptions is unclear; is the prescribed substrate the lips, tongue, cheek, gums, or teeth? Like the nose, all parts of the mouth are not particularly suited for use as a scribal substrate, with their contoured and soft fleshy

47 Shorshe haShemot s. v. געונם. The spell is further embellished with an accompanying incantation. 48 Rebiger 2017, 354. See also Marcus 2015, esp. chapter 2. See Shorshe haShemot s.v. פתחיאל for a spell to be written on a mother's breast immediately prior to nursing, with the intended effect of increasing the intelligence of the child, and Ross. MS 356f. 110v prescribing an angelic adjuration to be written on glass and dissolved in water, both invoking a supernatural entity strikingly similarly named as that adjured in the medieval Ashkenazic magical child-initiation rites.

49 Shorshe haShemot s. v. שר

50 See b. Hul. 53a.

51 Licking has a historical and cross-cultural association with healing, hence the English idiom "to lick one's wounds."

52 See, e.g. Shorshe haShemot s.v. שברירי II. 
quality. Perhaps this material-physical aspect of the substrate explains the dearth of such spells.

\subsection{Snake Deer Skin}

Readers of the medieval Jewish grimoire literature at times reacted with scribal violence to the materials that their texts prescribed. One such example occurred with Vat. Rossini MS 356, written in Camerino, Italy in the year 1412 (see above, 2.1.3). Here, on folio 96r, we find a spell for path-jumping. ${ }^{53}$ The text instructs that the practitioner is to arise in the morning, make himself pure, anoint with olive oil, and then execute the creation of the amulet by writing the incantation on a certain parchment. Here we find a marginal correction by an untrained hand, in which the reader both scratched out and drew a line across the erasure, where the prescribed parchment substrate originally was written.

\section{Vat. Rossini 356f. 96r}

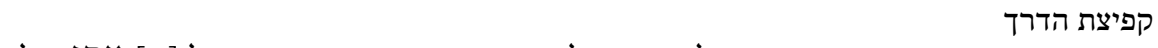

ישכים בבקר קודם עמוד השחר ויטבול וימשח כל גופו בשמן זית ויכתוב בעור של [...] צבי אילו

השמות [...]

\section{Path-jumping}

He should arise in the morning before daybreak, ritually immerse, anoint his entire body with olive oil, and write on the skin of a [erasure] DEER these divine names [...]

Vat. ebr. $243 \$ 102$

קפיצת הדרך מה"ר אליעזר מגרמיש"א: ישכים בבוקר קודם עלות עמוד השחר ויטבול ויסוך כל גופו בשמן זית ויכתוב אילו השמות בעור נחש [....

Path-jumping from Eleazar of Worms:

He should arise in the morning before daybreak, ritually immerse, rub down his entire body with olive oil, and write these divine names on the skin of a snake [...]

When we find the identical spell ${ }^{54}$ in another Vatican MS, we discover what the reader of Rossini 356 found so objectionable. The amulet is to be written on snake skin. Although snakes are not characterized as particularly gruesome animals in classical rabbinic literature, ${ }^{55}$ some rabbinic sages did hold a particular hatred for them. ${ }^{56}$

53 Path-jumping is a magical process by which a journey is shortened. See Verman/Adler 1993/94. 54 Although the two spells do vary slightly: the version in Vat. ebr. 243 provides an ascription, the verb for "anoint" differs from one text to the other, and the word order is slightly different.

55 Indeed, snake skin is identified as the material of the primordial clothing of Gen 3:21 in a statement ascribed to R. Eliezer in Midrash Shoher Tov 92:6 and Pirqe deRabbi Eliezer 20.

56 E. g. R. Akiva in Mekhilta Beshallah 2. 
Although it is possible that the reader was not actually objecting to the snake skin due to its grotesque nature, but rather due to a variant in another manuscript to which they had access, I find this unlikely. In marking a manuscript with a marginal note or correction, Jewish readers of texts nearly always appended a partially explanatory note such as "should read: X," and "in another manuscript: X." This was not a correction of the spell to what it was supposed to be, but a visceral alteration of the text. We can perceive the emotional disturbance of the reader in the mode of the correction; the word "snake" is both scratched out and a strike mark is drawn over it. It is noteworthy that none of the other spells prescribed in this short grimoire are of a grotesque nature.

\section{Conclusions}

While in many cases there is a clear correspondence between the media prescribed and the intended effect, that is not always so. Writing substrates and inks may be selected due to their perceived metaphysical or physical connection to the desired effect or locus of effect (as with blood, amniotic sac, forehead, hand, and mouth), or symbolism (as with apples).

In some instances, the connection may have been clear to the scribe-author, but is lost on us. In others, such as many of the spells recorded in Vat. ebr. 242, it may be that the author is including the use of such grotesque materia magica with the sole intention of their shock-value, and making the spells more believable to the consumerreader.

I suspect, though this cannot be proven until we have a fully descriptive catalog of both early and late medieval Jewish magic, that there is a sharp trend in later medieval Jewish magic away from the more grotesque scribal media prescribed by earlier practitioner-scribes. The rabbinization of magic in post-15th century European magic tradition is a subject that requires further research, and may have had a profound effect on the materia magica prescribed in Jewish magic texts in the late medieval and early modern periods. We see this development (potentially) at work in the censorship of grotesque materials in earlier grimoires (see above, 4.6). This theory might be tested by searching later medieval magic for innovative magic requiring the usage of grotesque media. If we can find a source or ancestor of each grotesque spell in an earlier source, i. e., if we cannot ascribe innovation to any of the grotesque spells found in late medieval Jewish magic, it may very well be due to a conscious eschewing of these materials that are so characteristic of earlier medieval Jewish magic. 


\section{Bibliography}

Amirav, Hagit (2005), "Drawing and Writing: A Fourth-Century Magical Spell from Oxyrhynchus", in: Shaul Shaked (ed.), Officina Magica: Essays on the Practice of Magic in Antiquity (Studies in Judaica 4), Leiden, 125-140.

Beit-Arié, Malachi/Pasternak, Nurit (2008), Hebrew Manuscripts in the Vatican Library-Catalogue, Compiled by the Staff of the Institute of Microfilmed Hebrew Manuscripts, Jewish National and University Library, ed. by Benjamin Richler, Vatican City.

Bohak, Gideon (2008), Ancient Jewish Magic: A History, Cambridge.

Geller, Markham (2000), “An Akkadian Vademecum in the Babylonian Talmud”, in: Samuel Kottek, et al. (eds.), From Athens to Jerusalem:Medicine in Hellenized Jewish Lore and in Early Christian Literature, Rotterdam, 13-32.

Gruenwald, Ithamar (2011), “When Magical Techniques and Mystical Practices Become Neighbors: Methodological Considerations", in: Gideon Bohak, Yuval Harari and Shaul Shaked (eds.), Continuity and Innovation in the Magical Tradition (Jerusalem Studies in Religion and Culture 15), Leiden, 159-186.

Idel, Moshe (2006), Nocturnal Kabbalists, Jerusalem.

Marcus, Ivan (2015), Rituals of Childhood: Jewish Acculturation in Medieval Europe, New Haven.

Margalioth, Mordecai (ed.) (1966), Sepher Ha-Razim: A Newly Recovered Book of Magic from the Talmudic Period, Collected from Genizah Fragments and other Sources, Jerusalem.

Rebiger, Bill (2017), “'Write on Three Ribs of a Sheep': Writing Materials in Ancient and Medieval Jewish Magic", in: Irina Wandrey (ed.), Jewish Manuscript Culture: New Perspectives (Studies in Manuscript Cultures 13), Berlin, 339-359.

Saar, Ortal-Paz (2017), Jewish Love Magic: From Late Antiquity to the Middle Ages (Magical and Religious Literature of Late Antiquity 6), Leiden.

Satlow, Michael (1994), “'Wasted Seed': The History of a Rabbinic Idea”, in: Hebrew Union College Annual 65, 137-175.

Schäfer, Peter/Shaked, Shaul (eds.) (1994), Magische Texte aus der Kairoer Geniza 1 (Texte und Studien zum antiken Judentum 42), Tübingen.

Swartz, Michael D. (2006), “Ritual Procedures in Magical Texts from the Cairo Genizah”, in: Jewish Studies Quarterly 13 (4), 305-318.

Tov, Emanuel (2004), Scribal Practices and Approaches Reflected in the Texts Found in the Judean Desert (Studies on the Texts of the Desert of Judah 54), Leiden.

Verman, Mark/Adler, Shulamit H. (1993/94), “Path Jumping in the Jewish Magical Tradition”, in: Jewish Studies Quarterly 1 (2), 131-148.

Zacuto, Abraham b. Samuel (31962), Sefer Yuhasin, ed. by Abraham H. Freimann, Jerusalem.

Zacuto, Moses (1998), Shorshe haShemot, Jerusalem. 
